\title{
FLUORESCENCE CHANGES IN AMINE MODEL SYSTEMS RELATED TO FISH DETERIORATION
}

Santiago Aubourg* and José M. Gallardo

Instituto de Investigaciones Marinas (CSIC)

c/ E. Cabello, 6

36208-VIGO (Spain)

* Correspondent:

Fax: $\quad+34-86-292762$

E-mail: $\quad$ saubourg @ iim.csic.es 


\section{SUMMARY}

Earlier studies have investigated, fluorescence at different excitation/emission maxima during common fish processing. A shift towards higher wavelength maxima was observed and measured as the ratio between absorption at two of the maxima tested. This fluorescence ratio $(\delta F)$ value correlated with increased fish damage. In the present work, different kinds of amines were tested to compare the fluorescence produced with that measured during fish processing. Amines with different substitution degree, and primary amines with different steric hindrance and chain length were reacted with cod liver oil and glutaraldehyde at $30^{\circ} \mathrm{C}$ in model systems.

All the amine classes produced changes in the fluorescent properties of the systems, higher $\delta \mathrm{F}$ values being associated with lower degree of substitution and steric hindrance of the $-\mathrm{NH}_{2}$ group, and also as a result of a longer chain length and higher concentration of the amine compound.

Running title: $\quad$ Amines producing fluorescence changes

Key Words: Cod liver oil, fish deterioration, glutaraldehyde, lipid oxidation, steric hindrance, substitution degree. 
Some products of reaction of amines and lipid oxidation products during food deterioration have been detected by increase in fluorescence, usually at a single excitation/emission wavelength maximum (Maruf et al., 1990; Lubis \& Buckle, 1990). This was thought to be a useful index of lipid deterioration, although most results have been complementary to other more established measurements of food deterioration (Melton, 1983; Smith et al., 1990).

Our previous studies of lipid damage by means of the fluorescence properties of the compounds formed during fish processing, tested different excitation/emission maxima. Relatively more fluorescence was observed at higher wavelengths maxima as quality of the fish decreased. This fluorescence shift was measured as the ratio between two of the maxima tested $(393 / 463 \mathrm{~nm}$ and $327 / 415 \mathrm{~nm})$ and proved to be a more effective index of fish quality than other common quality assessment methods (Aubourg et al., 1992, 1995 \& 1997).

The present work reports an investigation of this fluorescence ratio $(\delta \mathrm{F})$ in model amine systems, comparing different kinds of amines (substitution degree, steric hindrance and chain length). For this purpose, amines have been reacted at $30^{\circ} \mathrm{C}$ using cod liver oil (CLO) as generator of lipid oxidation compounds and with glutaraldehyde (GL). The influence of the amine content and the time of reaction were also evaluated. 
All chemicals were reagent grade (E. Merck, Darmstadt, Germany).

CLO (Bama Geve, S. A., Barcelona, Spain) was obtained from a commercial source. It was stored under $\mathrm{N}_{2}$ at $4^{\circ} \mathrm{C}$. Before employing it, acid value (1.1 mg KOH/g), peroxide value (2.4 meq $\mathrm{O}_{2} / \mathrm{Kg}$ ) (Williams, 1950) and fatty acid composition (Medina et al., 1994) were analyzed. The following proportions (\%) of the major fatty acids were

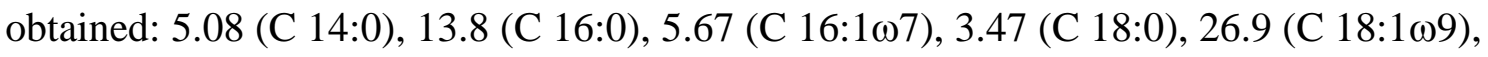

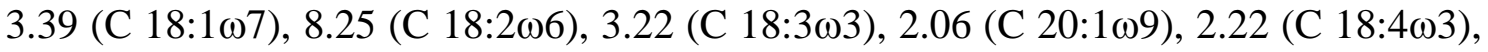

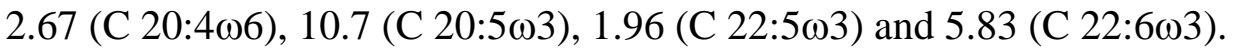

\section{Model systems preparation}

All the reacting mixtures were incubated in triplicate and sampled at 1, 7 and 25 days for fluorescence analysis. $25 \mathrm{ml}$ of each reacting mixture were placed in $30 \mathrm{ml}$ stoppered tubes in dark at $30^{\circ} \mathrm{C}$ without stirring. Blanks consisted of the individual starting compounds under the same reaction conditions.

\section{Amine substitution degree and concentration}

A $0.05 \mathrm{M}$ solution of amine (n-butylamine, BA; dibutylamine, DBA; tributylamine, TBA) was prepared in aq. 86\% ethanol. CLO portions ( 0.5 g) were mixed with $0.1,0.4,2$ and $10 \mathrm{ml}$ of each amine solution and made up to $25 \mathrm{ml}$ with aq. $86 \%$ ethanol leading to $0.2,0.8,4$ and $20 \mathrm{mM}$ amine mixtures, respectively.

Glutaraldehyde (GL) solution (5 ml, $1 \mathrm{M}$ in aq. ethanol $86 \%$ ) was mixed with amine (BA, DBA and TBA) solution ( $1 \mathrm{ml}, 1 \mathrm{M}$ in aq. ethanol 86\%) and made up to 25 $\mathrm{ml}$ with aq. $86 \%$ ethanol (40 $\mathrm{mM}$ amine).

\section{Chain length and steric hindrance of primary amines}


Methylamine (MA) and ethylamine (EA) solutions (0.1 M) were prepared in aqueous 86\% ethanol; propylamine (PA), octylamine (OA), n-butylamine (BA), isobutylamine (i-BA), sec-butylamine (s-BA) and tert-butylamine (t-BA) solutions were prepared $(0.1 \mathrm{M})$ in chloroform. CLO $(0.5 \mathrm{~g})$ was mixed with $5 \mathrm{ml}$ of each amine solution; then, aq. $86 \%$ ethanol and chloroform were added in order to obtain a $25 \mathrm{ml}$ solution in the 1:1 ratio for both solvents.

\section{Fluorescence analysis}

Fluorescence measurements (Perkin-Elmer LS 3B) were made at 327/415 and 393/463 nm excitation/emission maxima. Relative fluorescences (RF) were calculated as $\mathrm{RF}=\mathrm{F} / \mathrm{F}_{\mathrm{st}}$, where $\mathrm{F}$ is the sample fluorescence at each excitation/emission maximum, and $\mathrm{F}_{\mathrm{st}}$ is the fluorescence intensity of a quinine sulphate solution $\left(1 \mu \mathrm{g} \mathrm{ml} \mathrm{l}^{-1}\right.$ in $\left.0.05 \mathrm{M} \mathrm{H}_{2} \mathrm{SO}_{4}\right)$ at the corresponding wavelength. The fluorescence ratio $(\delta \mathrm{F})$ was calculated as: $\delta \mathrm{F}=\mathrm{RF}_{393 / 463 \mathrm{~nm}} / \mathrm{RF}_{327 / 415 \mathrm{~nm}}$.

\section{Statistical analysis}

Fluorescence ratios $(\delta F)$ were subjected to one-way ANOVA (Sokal \& Rohlf, 1981); $\mathrm{p}<0.05$.

\section{RESULTS AND DISCUSSION}

\section{Influence of the substitution degree}


As a first step to analyze the effect of the substitution degree on the ability of amine molecules to change the fluorescent properties of the reacting mixtures, a comparison between a primary (BA), a secondary (DBA) and a tertiary (TBA) amine was carried out. The fluorescence ratio $(\delta \mathrm{F})$ obtained in the different reacting mixtures with CLO are shown in Table 1 . For each amine $\delta$ F increased significantly with time. The most substituted amine (TBA) showed a much lower $\delta \mathrm{F}$ value than the primary one (BA); DBA showed an intermediate value.

In order to study in a more particular way the effect of the substitution degree, the interaction between the same amines (BA, DBA and TBA) and a dialdehyde molecule (glutaraldehyde, GL) was tested. A smaller $\delta \mathrm{F}$ value was detected as a result of increasing the substitution degree in the amino compound, leading again to the decreasing sequence: BA > DBA > TBA (Table 2). Increased reaction times produced progressively greater $\delta \mathrm{F}$ for all three amines.

These results can be explained by the greater reactivity of non-substituted amines since nucleophilicity of the nitrogen atom is not hindered and it interacts easily with lipid oxidation compounds.

\section{Influence of the steric hindrance in primary amines}

As primary amines showed the highest $\delta \mathrm{F}$ value, the effect of their steric hindrance on the fluorescence formation was investigated in model systems using BA, iBA, s-BA and t-BA. For all the amines (Table 3), a significant increase was obtained with the reaction time. From the beginning of the reaction (day 1) differences between amines were observed. After 25 days, the following decreasing $\delta F$ value was obtained: i-BA $>$ BA $>$ s-BA $>$ t-BA. Results can be explained on the basis that a higher steric 
hindrance has led to a lower ability to produce change in the fluorescence properties of the reaction mixture.

In both the $\mathrm{BA}$ and $\mathrm{i}-\mathrm{BA}$ the $-\mathrm{NH}_{2}$ group is linked to a primary carbon atom. However, the positive inductive effect of the iso-butyl radical is known to be bigger than the one of the butyl radical (Fieser \& Fieser, 1966), so that the corresponding $-\mathrm{NH}_{2}$ group may react easier (higher nucleophilicity) and produce a greater $\delta \mathrm{F}$.

\section{Influence of the chain length in primary amines}

All the amines tested (MA, EA, PA, BA and OA) showed an increase in the $\delta \mathrm{F}$ value as the reaction time increased (Table 4). A comparison between amines after 25 days of reaction, led to the following decreasing sequence: OA > BA, PA > EA, MA. The present results led to the conclusion that the increasing chain length exerts a positive effect on the $\delta \mathrm{F}$ value. Possibly longer chain length provides the amine molecule with a more lipid-type structure, so that interaction with lipid oxidation compounds would be facilitated.

A similar conclusion about the effect of the aldehydes chain length was obtained by Montfoort et al. (1987), where a comparative study of fluorescence formation was carried out by exposing phosphatidyl ethanolamine containing liposomes to a variety of aldehydes. The fluorescence formation increased with chain lengths in saturated aldehydes and this effect was attributed to the increasing lipophilic character of the aldehydes.

\section{Influence of the amine content}

Model systems containing CLO and amines (BA, DBA and TBA) at different concentrations were tested. The $\delta \mathrm{F}$ was studied and results are given in Table 5 . 
Although differences were not always statistically significant, $\delta \mathrm{F}$ values for each amine increased with concentration at each reaction time, differences were more marked after reaction for 25 days.

These observations on $\delta \mathrm{F}$ values indicate that greater attention should be given to the measurement of these interaction compounds during processing of food materials with a high content of amine constituents such lysine and other basic amino acids (Navarro, 1991).

\section{CONCLUSIONS}

The present investigation has provided a comparison between different kinds of amines in terms of their ability in producing interaction compounds with fluorescence properties similar to those detected during fish processing (sterilisation, cooking and chilling) (Aubourg et al., 1992, 1995 \& 1997). Similar bathochromic shifts, accelerated by the temperature and amine reactivity, were observed presumably as a result of a formation of compounds with progressively increasing numbers of double bonds (Pokorný, 1977; Gardner, 1979).

Fluorescent compounds are known to be formed as a result of lipid oxidation in the presence of amine molecules (Montfoort et al., 1987; Lubis \& Buckle, 1990; Aubourg, 1993) and a great attention has been given to the oxidation compounds formation (Frankel, 1991). From the present results, it is concluded that amine compounds would also play an important role in the fluorescence formation. The absence of such compounds (CLO controls) has shown to produce very little $\delta \mathrm{F}$. As a 
result, it is concluded that both kinds of compounds (lipid oxidation molecules and amines) are necessary in order to obtain the fluorescent development.

From a qualitative point of view, amines with a lower substitution and steric hindrance, and with a higher chain length have been found to produce a higher fluorescence ratio. From a quantitative point of view, amines had been supposed to play a catalytic effect on the condensation reactions (Suyama et al., 1981; Pokorný et al., 1987). However, the present results indicate that the formation of fluorescent compounds would depend not only on the presence of lipid oxidation products but also on the amine content.

\section{Acknowledgements}

To Mr. Oscar Bellón for technical assistance and the Xunta de Galicia for financial support (Project XUGA 402 01B93). 


\section{REFERENCES}

Aubourg, S. (1993). Review: Interaction of malondialdehyde with biological moleculesnew trends about reactivity and significance. International Journal of Food Science and Technology 28, 323-335.

Aubourg, S., Medina, I. \& Pérez-Martín, R. (1995). A comparison between conventional and fluorescence detection methods of cooking-induced damage to tuna fish lipids. Zeitschrift für Lebensmittel Untersuchung und Forschung 200, 252-255.

Aubourg, S., Pérez-Martín, R., Medina, I. \& Gallardo, J. (1992). Fluorescence formation during albacore (Thunnus alalunga) thermal processing. Zeitschrift für Lebensmittel Untersuchung und Forschung 195, 332-335.

Aubourg, S., Sotelo, C. \& Gallardo, J. (1997). Quality assessment by fluorescent compounds measure during storage of sardine (Sardina pilchardus) at $0^{\circ} \mathrm{C}$ and $15^{\circ}$ C. Journal Food Science 62 (2), 000.

Fieser, L. \& Fieser, M. (1966). Qumica Orgánica Superior. Ediciones Grijalbo, S. A., Barcelona (Spain), p. 481.

Frankel, E. (1991). Review: Recent advances in lipid oxidation. Journal of the Science of Food and Agriculture 54, 495-511.

Gardner, H. (1979). Lipid hydroperoxide reactivity with proteins and amino acids. Journal of the Agricultural and Food Chemistry 27, 220-229.

Lubis, Z. \& Buckle, K. (1990). Rancidity and lipid oxidation of dried-salted sardines. International Journal of Food Science and Technology 25, 295-303. 
Maruf, F., Ledward, D., Neale, R. \& Poulter, R. (1990). Chemical and nutritional quality of Indonesian dried-salted mackerel (Rastrelliger kanagurta). International Journal of Food Science and Technology 25, 66-77.

Medina, I., Linares, F. \& Garrido, J. (1994). Use of a packed programmed-temperature vaporizer injector in the solvent elimination mode for the determination of fatty acid methyl esters by gas chromatography. Journal of Chromatography 659, 472-476.

Melton, S. (1983). Methodology for following lipid oxidation in muscle foods. Food Technology 37, 105-111, 116.

Montfoort, A., Bezstarosti, K., Groh, M. \& Koster, J. (1987). The influence of the chain length of aldehydes on the fluorescence of chromolipids. Federation of the European Biochemical Societies Letters 226, 101-104.

Navarro, P. (1991). Valor nutritivo del pescado. I. Pescado fresco. Revista de Agroquímica y Tecnología Alimentaria 31, 330-342.

Pokorný, J. (1977). Interactions of oxidised lipids with proteins. Rivista Italiana delle Sostanze Grasse 54, 389-393.

Pokorný, J., Janitz, W., Víden, I., Velísek, J., Valentová, H. \& Davídek, J. (1987). Reaction of oxidized lipids with proteins. Part 14. Aldolization reactions of lower alkanals in presence of non lipidic substances. Nahrung 31, 63-70

Smith, G., Hole, M. \& Hanson, S. (1990). Assessment of lipid oxidation in Indonesian salted-dried Marine catfish (Arius thalassinus). Journal of the Science of Food and Agriculture 51, 193-205.

Sokal, R. \& Rohlf, F. (1981). Biometry. Second edition. Freeman, W. and Company, San Francisco, USA, pp. 208-270. 
Suyama, K., Arakawa, T. \& Adachi, S. (1981). Free fatty aldehydes and their aldol condensation products in heated meats. Journal of the Agricultural and Food Chemistry 29, 875-878.

Williams, K. (1950). Oils, fats and fatty foods. Their practical examination. $3^{\text {rd }}$ edition. J. \& A. Churchill Ltd, London, UK, pp. 53-54, 107-108. 
TABLE 1

Mean fluorescence ratio $(\delta \mathrm{F})$ values $( \pm \mathrm{SD}, \mathbf{n}=3)^{*}$ obtained by reaction at $30^{\circ} \mathrm{C}$ of cod liver oil (CLO) and $20 \mathrm{mM}$ amines with different substitution degree**

Reacting Time (days)

\begin{tabular}{cccc} 
Reacting Mixture & \multicolumn{1}{c}{1} & $\frac{7}{25}$ \\
CLO & $1.72 \pm 0.03 \mathrm{a}^{*}$ & $1.72 \pm 0.11 \mathrm{a}$ & $2.44 \pm 0.6 \mathrm{a}$ \\
$\mathrm{CLO}+\mathrm{BA}$ & $4.93 \pm 0.16 \mathrm{c}$ & $34.3 \pm 1.7 \mathrm{~d}$ & $144 \pm 7.2 \mathrm{~d}$ \\
$\mathrm{CLO}+$ DBA & $4.76 \pm 0.31 \mathrm{c}$ & $10.6 \pm 0.01 \mathrm{c}$ & $32.1 \pm 0.9 \mathrm{c}$ \\
$\mathrm{CLO}+$ TBA & $2.89 \pm 0.15 \mathrm{~b}$ & $5.45 \pm 0.16 \mathrm{~b}$ & $10.4 \pm 0.5 \mathrm{~b}$
\end{tabular}

* Values in the same column followed by different letters are significantly different ( $\mathrm{p}<$ 0.05). Results correspond to $20 \mathrm{mM}$ amine mixtures. Initial $\delta \mathrm{F}$ value of CLO was 1.75 .

** Abbreviations: BA (n-butylamine), DBA (dibutylamine) and TBA (tributylamine). 
TABLE 2

Mean fluorescence ratio $(\delta \mathrm{F})$ values $( \pm \mathrm{SD}, \mathbf{n}=3)^{*}$ obtained by reaction at $30^{\circ} \mathrm{C}$ of glutaraldehyde (GL) and $40 \mathrm{mM}$ amines with different substitution degree**

\section{Reacting Time (days)}

\begin{tabular}{|c|c|c|c|}
\hline Reacting Mixture & 1 & 7 & 25 \\
\hline GL & $3.53 \pm 0.12 \mathrm{a}^{*}$ & $3.47 \pm 0.03$ a & $3.27 \pm 0.02 a$ \\
\hline $\mathrm{GL}+\mathrm{BA}$ & $5.49 \pm 0.40 \mathrm{c}$ & $9.49 \pm 0.19 \mathrm{~d}$ & $11.2 \pm 0.26 \mathrm{~d}$ \\
\hline $\mathrm{GL}+\mathrm{DBA}$ & $4.34 \pm 0.02 b$ & $4.88 \pm 0.02 \mathrm{c}$ & $6.03 \pm 0.05 c$ \\
\hline GL + TBA & $3.75 \pm 0.03 \mathrm{a}$ & $3.70 \pm 0.01 b$ & $3.78 \pm 0.03 b$ \\
\hline
\end{tabular}

* Values in the same column followed by different letters are significantly different $(\mathrm{p}<$ 0.05). Initial $\delta F$ value of GL was 3.54.

** Abbreviations as expressed in Table 1. 


\section{TABLE 3}

Mean fluorescence ratio $(\delta \mathrm{F})$ values $( \pm \mathrm{SD}, \mathrm{n}=3)^{*}$ produced by reaction at $30^{\circ} \mathrm{C}$ of cod liver oil (CLO) and $20 \mathrm{mM}$ primary amines with different steric

hindrance**

\section{Reacting Time (days)}

\begin{tabular}{|c|c|c|c|}
\hline Reacting Mixture & 1 & 7 & 25 \\
\hline CLO & $2.30 \pm 0.07 \mathrm{a}^{*}$ & $2.26 \pm 0.55 \mathrm{a}$ & $2.37 \pm 0.47 \mathrm{a}$ \\
\hline $\mathrm{CLO}+\mathrm{BA}$ & $5.85 \pm 0.25 \mathrm{~d}$ & $17.2 \pm 1.0 \mathrm{~d}$ & $37.6 \pm 2.7 \mathrm{~d}$ \\
\hline $\mathrm{CLO}+\mathrm{i}-\mathrm{BA}$ & $5.80 \pm 0.29 \mathrm{~d}$ & $17.3 \pm 1.0 \mathrm{~d}$ & $43.4 \pm 1.7 \mathrm{e}$ \\
\hline $\mathrm{CLO}+\mathrm{s}-\mathrm{BA}$ & $3.35 \pm 0.15 \mathrm{c}$ & $6.80 \pm 0.41 \mathrm{c}$ & $12.6 \pm 0.5 \mathrm{c}$ \\
\hline $\mathrm{CLO}+\mathrm{t}-\mathrm{BA}$ & $2.80 \pm 0.19 b$ & $4.16 \pm 0.28 b$ & $6.20 \pm 0.45 b$ \\
\hline
\end{tabular}

* Values in the same column followed by different letters are significantly different $(\mathrm{p}<$ 0.05). Initial $\delta F$ value of CLO was 2.28.

** Abbreviations: i-BA (iso-butylamine), s-BA (sec-butylamine), t-BA (tertbutylamine); BA as indicated in Table 1. 
TABLE 4

Mean fluorescence ratio $(\delta F)$ values $( \pm S D, n=3) *$ obtained by reaction at $30^{\circ} \mathrm{C}$ of cod liver oil (CLO) and $20 \mathrm{mM}$ primary amines with different chain length**

Reacting time (days)

\section{Reacting Mixture}

CLO

$\mathrm{CLO}+\mathrm{MA}$

CLO + EA

$\mathrm{CLO}+\mathrm{PA}$

$\mathrm{CLO}+\mathrm{BA}$

$\mathrm{CLO}+\mathrm{OA}$

1

$2.30 \pm 0.07 \mathrm{a}^{*}$

$6.16 \pm 0.23 \mathrm{c}$

$5.09 \pm 0.04 \mathrm{~b}$

$5.35 \pm 0.29$ bc

$16.2 \pm 1.8$ bc

$5.85 \pm 0.25$ c

$5.70 \pm 0.26$ с
$17.6 \pm 1.5 \mathrm{~cd}$

$14.5 \pm 0.3 b$

$17.2 \pm 1.0 \mathrm{~cd}$

$2.26 \pm 0.55$ a

$2.37 \pm 0.47$ a

$29.5 \pm 1.7 b$

$31.5 \pm 1.6 \mathrm{~b}$

$35.1 \pm 1.6$ c

$37.6 \pm 2.7 \mathrm{c}$

$19.7 \pm 1.3 \mathrm{~d}$

$44.9 \pm 1.5 \mathrm{~d}$

* Values in the same column followed by different letters are significantly different $(\mathrm{p}<$ 0.05). Initial $\delta \mathrm{F}$ value of CLO was 2.28.

** Abbreviations: MA (methylamine), EA (ethylamine), PA (propylamine), OA (octylamine); BA as indicated in Table 1. 
TABLE 5: Mean fluorescence ratio $(\delta F)$ values $( \pm S D, n=3) *$ obtained by reaction at $30{ }^{\circ} \mathrm{C}$ of cod liver oil (CLO) and different amine concentrations ${ }^{* *}$

\section{Reacting Time (days)}

\begin{tabular}{|c|c|c|c|c|}
\hline \multirow[b]{2}{*}{ Amine } & \multirow[b]{2}{*}{$\begin{array}{l}\text { Concentration } \\
\text { of amine (mM) }\end{array}$} & \multicolumn{3}{|c|}{ Reacting Time (days) } \\
\hline & & 1 & 7 & 25 \\
\hline BA & 0.2 & $2.25 \pm 0.24 a^{*}$ & $6.76 \pm 3.6 \mathrm{a}$ & $13.8 \pm 4.3 \mathrm{a}$ \\
\hline$"$ & 0.8 & $2.51 \pm 0.12 \mathrm{a}$ & $9.55 \pm 1.0 \mathrm{a}$ & $44.4 \pm 3.2 \mathrm{~b}$ \\
\hline$"$ & 4 & $3.31 \pm 0.10 b$ & $16.7 \pm 0.7 b$ & $70.0 \pm 5.1 \mathrm{c}$ \\
\hline$"$ & 20 & $4.93 \pm 0.45 \mathrm{c}$ & $34.3 \pm 1.7 \mathrm{c}$ & $144 \pm 7.2 \mathrm{~d}$ \\
\hline DBA & 0.2 & $1.91 \pm 0.08 \mathrm{a}$ & $2.02 \pm 0.13 \mathrm{a}$ & $3.42 \pm 0.26$ \\
\hline$"$ & 0.8 & $2.01 \pm 0.09 \mathrm{a}$ & $3.13 \pm 0.36 b$ & $6.30 \pm 1.0 \mathrm{~b}$ \\
\hline$"$ & 4 & $2.47 \pm 0.12 b$ & $5.38 \pm 0.43 c$ & $12.8 \pm 0.59 \mathrm{c}$ \\
\hline$"$ & 20 & $4.76 \pm 0.31 \mathrm{c}$ & $10.6 \pm 0.24 \mathrm{~d}$ & $32.1 \pm 0.24 \mathrm{~d}$ \\
\hline TBA & 0.2 & $1.79 \pm 0.08 \mathrm{a}$ & $1.87 \pm 0.09 \mathrm{a}$ & $2.24 \pm 0.13$ \\
\hline$"$ & 0.8 & $1.93 \pm 0.02 a b$ & $2.34 \pm 0.11 b$ & $3.65 \pm 0.6 \mathrm{a}$ \\
\hline$"$ & 4 & $2.06 \pm 0.09 b$ & $3.02 \pm 0.27 \mathrm{c}$ & $6.14 \pm 1.0 \mathrm{~b}$ \\
\hline$"$ & 20 & $2.89 \pm 0.15 \mathrm{C}$ & $5.45 \pm 0.16 \mathrm{~d}$ & $10.4 \pm 0.53 c$ \\
\hline
\end{tabular}

* Abbreviations as indicated in Table 1. Four different concentrations (20, 4, 0.8 and $0.2 \mathrm{mM}$ ) for each amine were employed. Initial $\delta \mathrm{F}$ value of CLO was 1.75.

** Values in the same column for each amine followed by different letters are significantly different $(\mathrm{p}<0.05)$. 